\title{
EQUiLIBRIUM
}

Quarterly Journal of Economics and Economic Policy

2015 VOLUME 10 ISSUE 1, March

p-ISSN 1689-765X, e-ISSN 2353-3293

www.economic-policy.pl

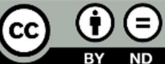

Woźniak-Jęchorek, B. (2015). Institutional Determinants of Regional Diversity of Labor Market in Poland. Equilibrium. Quarterly Journal of Economics and Economic Policy, 10(1), pp. 129-151, DOI: http://dx.doi.org/10.1 2775/EQUIL.2015.007

\author{
Beata Woźniak-Jęchorek ${ }^{*}$ \\ Poznań University of Economics, Poland
}

\section{Institutional Determinants of Regional Diversity of Labor Market in Poland ${ }^{* *}$}

JEL Classification: $B 15 ; B 25 ; B 52 ; J 08$

Keywords: institutional economics; labor market; institutional unemployment; labor market's institutions

\begin{abstract}
The article focuses on regional diversity of the Polish Labor Market from institutional perspective. The Polish Labor Market is geographically diverse in terms of unemployment and employment rates, and also in terms of economic development. At the end of 2013 the difference between the lowest and the highest unemployment rate in the Polish regions was $12.1 \%$ (Wielkopolska located in the West Poland has unemployment rate of $9.6 \%$ and Warmia - Mazury in the East has unemployment of 21.7\%). The question arises whether this difference comes from the structural or institutional sources. The paper describe the character of Polish Labor Market, whereas in the second part, it traces the impact of institutional variables such as real wage, Kaitz index and Gender gap on the regional unemployment rate in 2002-2012 in Poland.
\end{abstract}

(C) Copyright Institute of Economic Research \& Polish Economic Society Branch in Toruń

Date of submission: December 10, 2014; date of acceptance: February 5, 2015

* Contact: b.wozniak@ue.poznan.pl, Poznań University of Economics, Al. Niepodległości 10, 61-875 Poznań, Poland

${ }^{* *}$ This text was presented during the $26^{\text {th }}$ Annual EAEPE (European Association for Evolutionary Political Economy) Conference 2014, Nicosia, Cyprus, which was held between the 6th-8th Nov 2014. 


\section{Introduction}

The economic crisis that first broke out in 2008 has taken a tremendous toll on labor markets across the EU. Unemployment figures have increased, while employment rates continue to fall. It has been observed that the crisis has served to accelerate previously existing structural trends, generating increasing inequality, polarization and atypical employment (Crisis takes its toll..., 2014, p. 27).

In this context, the Polish Labor Market is an interesting example of changing situation. On the one hand, in terms of economic growth, Poland remained "Green Island", but on the other hand, the Polish Labor Market remains highly diversified with some structural and institutional problems.

The aim of this paper is to present this regional diversity of the Polish Labor Market from the institutional perspective. The intellectual background of this text is based on institutional economics. As North (1990, p. 3) put it: "Institutions are the rules of the game in a society or, more formally, are the humanly devised constraints that shape human interaction". For labor market, the most important are: benefits, participation-friendly schemes, labor taxation, wage setting, employment protection legislation, union density and active labor market policies (skills developments, youth employment and job creation). Such institutions affect the efficiency of an economy. An economy with good institutions is more efficient in the sense that it takes less input to produce the same amount of output. Moreover, bad institutions lower incentives to invest, to work and to produce (Sala-iMartin, 2002).

An important part of labor market are also informal institutions such as human capital, social capital, religion, customs, norms and type of society. These institutions are especially important for the large labor market with diverse regional field, where cultural factors play a major role.

It is quite undisputable that in the beginning of the first decade of the $21^{\text {st }}$ century the major problems of the Polish Labor Market are: low activity of labor force - especially women, as well as, high unemployment and low employment rate. These three phenomena were geographically diverse. For instance - at the end of 2013 the difference between the lowest and the highest unemployment rate in the Polish regions was $12.1 \%{ }^{1}$. Although most of the labor market analysis focuses on the structural changes, it appears that the problem concerns the institutional changes. Therefore, the research problem of this article is to look closely at how institutions affect

${ }^{1}$ Wielkopolska located in the West Poland has the unemployment rate of $9.6 \%$ and Warmia - Mazury in the East has unemployment of $21.7 \%$. 
the unemployment and to analyze their impact on unemployment in different regions of Poland.

In the first part of this paper, I describe the character of the Polish Labor Market, whereas in the second part, I trace the impact of selected institutional variables such as real wage, Kaitz index and Gender gap on the regional unemployment rate in Poland in 2002-2012.

\section{Institutional Characteristics of Polish Labor Market}

Not a long time ago, in 2004, Poland was fighting very serious unemployment (20\% in 2002-2003). The transformation process imposed a radical change regarding rationalization and restructurization of employment, which was carried out in Poland in two waves. The first wave of restructurization (companies before 1989) was overlapped by the second wave, based on the development of the new IT based economy. Moreover, new restructurization of social services appeared, for example in education or health care. These two processes led, especially after 2001, to employment rationalization, forcing rapid economic growth, generated mainly by increasing productivity and the use of new technologies. The situation on the Polish Labor Market has also changed after Poland joined the EU system. Common European Labor Market has helped to solve the problem of Polish unemployment. Unfortunately, after 2008 the latest global economic crisis has affected the Polish Labor Market as well, and nowadays the rate of unemployment is still $13.4 \%$ (see Figure 1).

Figure 1. Annual GDP rate, employment and unemployment rate in the years 2003-2013

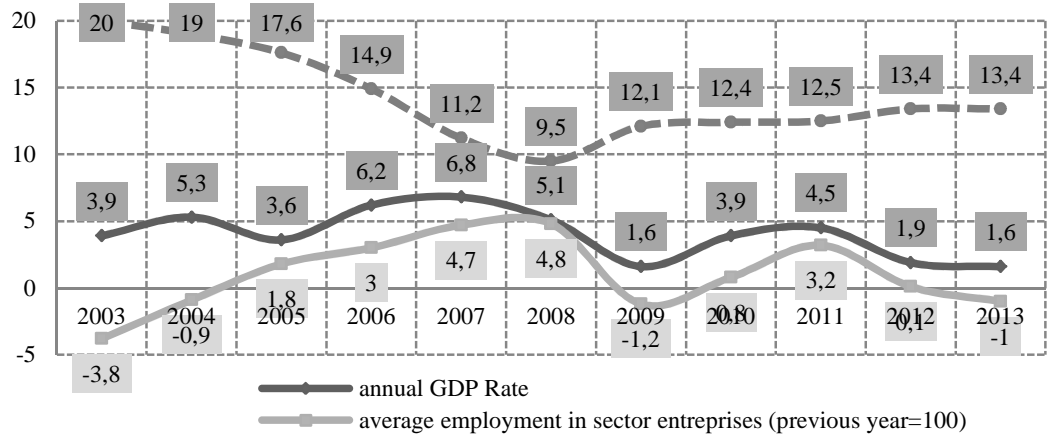

Source: own elaboration based on Statistical Yearbooks of GUS (GUS). 
While analyzing the data presenting by Eurostat, we do not see a serious problem of unemployment and employment in Poland, but the problem with the overall level of economic activity for the age group 15-64 years (see Table 1). In the years 2003-2013, we even observe a significant decrease of difference between Poland and EU28 in terms of employment and unemployment. However, European statistics do not show the real situation in Poland, because they are based on different definitions of workforce age (in Poland - 18/59-64 years ${ }^{2}$, than in the EU - 15/64 years).

Table 1. Activity, employment and unemployment in Poland vs. EU28

\begin{tabular}{|c|c|c|c|c|c|c|c|c|c|}
\hline \multirow[b]{2}{*}{ Year } & \multicolumn{3}{|c|}{$\begin{array}{l}\text { Activity rate } \\
\text { (15-64 years) }\end{array}$} & \multicolumn{3}{|c|}{$\begin{array}{l}\text { Employment rate } \\
\text { (15-64 years) }\end{array}$} & \multicolumn{3}{|c|}{$\begin{array}{l}\text { Unemployment rate } \\
\text { (15-64 years) }\end{array}$} \\
\hline & 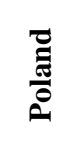 & 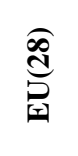 & 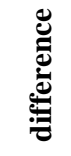 & $\begin{array}{l}\bar{\Xi} \\
\frac{\bar{E}}{0} \\
\stackrel{0}{0}\end{array}$ & 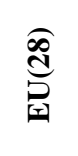 & 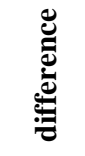 & 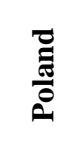 & 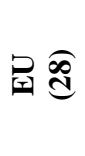 & 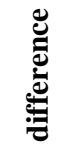 \\
\hline 2003 & 64 & 68,9 & $-4,9$ & 51,4 & 62,6 & $-11,2$ & 19,7 & 9,2 & 10,5 \\
\hline 2004 & 63,7 & 69,2 & $-5,5$ & 51,4 & 62,7 & $-11,3$ & 19,4 & 9,3 & 10,1 \\
\hline 2005 & 64,4 & 69,7 & $-5,3$ & 52,8 & 63,4 & $-10,6$ & 18 & 9,1 & 8,9 \\
\hline 2006 & 63,4 & 70,1 & $-6,7$ & 54,5 & 64,3 & $-9,8$ & 14 & 8,3 & 5,7 \\
\hline 2007 & 63,2 & 70,3 & $-7,1$ & 57 & 65,3 & $-8,3$ & 9,7 & 7,2 & 2,5 \\
\hline 2008 & 63,8 & 70,7 & $-6,9$ & 59,2 & 65,7 & $-6,5$ & 7,2 & 7,1 & 0,1 \\
\hline 2009 & 64,7 & 70,9 & $-6,2$ & 59,3 & 64,5 & $-5,2$ & 8,3 & 9 & $-0,7$ \\
\hline 2010 & 65,3 & 70,9 & $-5,6$ & 58,9 & 64 & $-5,1$ & 9,7 & 9,7 & 0 \\
\hline 2011 & 65,7 & 71,1 & $-5,4$ & 59,3 & 64,1 & $-4,8$ & 9,8 & 9,8 & 0 \\
\hline 2012 & 66,5 & 71,7 & $-5,2$ & 59,7 & 64,1 & $-4,4$ & 10,2 & 10,6 & $-0,4$ \\
\hline 2013 & 67 & 72 & -5 & 60 & 64,1 & $-4,1$ & 10,5 & 10,9 & $-0,4$ \\
\hline
\end{tabular}

Source: Rynek pracy w Polsce... (2014, p. 16).

Thus, in Poland we have a lower activity and lower employment than in the EU - particularly of women (see Fig. 2). For example, in 2011 Poland was inhabited by 38.5 million people including 23.6 million people at the working age. Among the people of working age - only 16.5 million people

\footnotetext{
${ }^{2}$ In 2013, the retirement age in Poland was raised to 67 years.
} 
were economically active (including women -7.4 million). In the fourth quarter of 2013, the most important reasons for inactivity were: a pension (indicated by nearly half of the economically inactive population), learning and raising qualifications, disease and disability (indicated by $13.9 \%$ of the economically inactive) and family responsibilities (11.1\% of passive population) (Rynek pracy w Polsce..., 2014, p. 3).

Figure 2. Employment rate total and women (18-59/64 years) in Poland in the years 2000-2012 (\%)

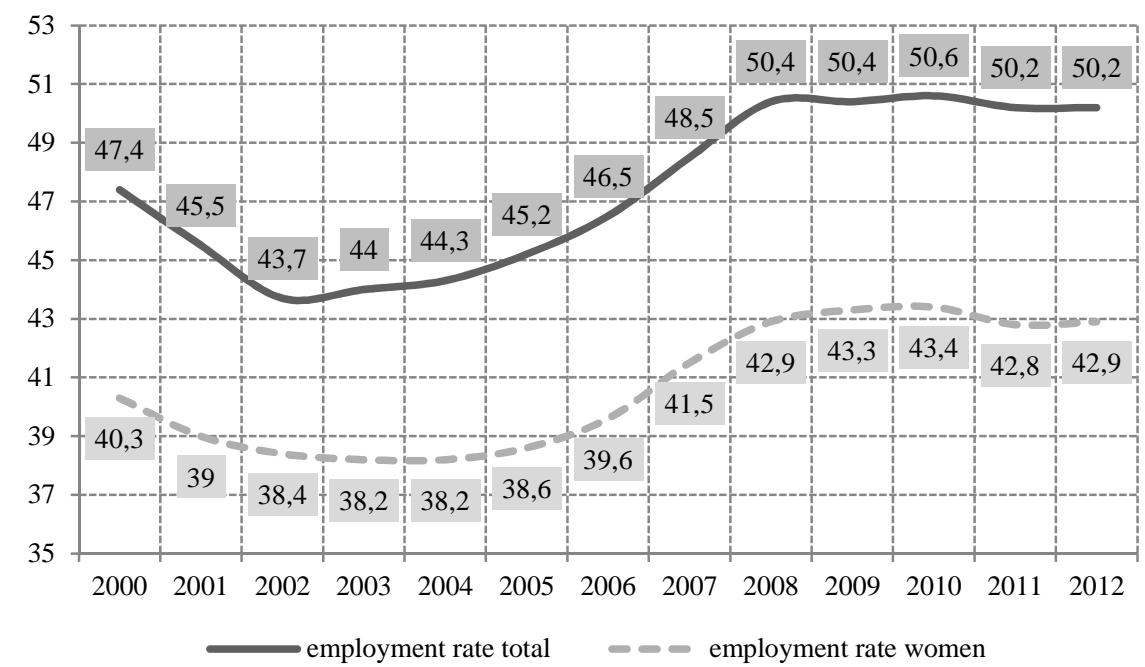

Source: own elaboration based on Statistical Yearbooks of GUS (GUS 2000-2014).

Low economic activity and low employment rates provoke questions about the institutional conditions of the labor market in Poland. Among the most important informal and formal institutions which affect the behavior of the labor market participants we can point out the following:

a) In the employer's environment:

- Perception of the hierarchy and the worker-employer distance,

- Acceptance of change - the need of regulation,

- Tax system (labor costs, tax wedge),

- Employment protection system (rules for employing, dismissing, and wage setting, e.g. the scope and level of wage negotiation and coordination, minimum wage system), 
- Social dialogue (including social goals and ways to achieve them by trade unions and employers' organizations, the level of unionization and wage bargaining system),

- Bureaucratic and financial obstacles for the development of entrepreneurship,

- Existence and size of the shadow economy.

b) In the employee's environment:

- Feminization vs. masculinization of social roles,

- Perception of leisure time and family (work life balance),

- Quality of social capital,

- Unemployment income protection (passive labor market policy) and assistance in finding and obtaining work (active policy),

- Social assistance, infrastructure of family support, educational policy, pension system,

- Professional and spatial mobility.

Institutional determinants of unemployment can be divided into those that affect the demand for labor and the supply of labor. The former include: employment protection legislation, labor taxation, the system of unemployment benefits, union density, and system of wage bargaining. The latter - the factors affecting the changes in labor supply: demographic and family policy, earlier deactivation and migrations.

In institutional analysis, the most important problem is the choice of one indicator, which allowed a total assessment of institutional change. In most cases, existing indicators describe reality at the macroeconomic level for the whole country. Therefore, they are useful in conducting regional analyzes. However, in order to illustrate national trends in institutional change we can use the following indices:

- Index of Economic Freedom in the labor market developed by the Heritage Foundation (published since 2005);

- Labor Market Efficiency Index published by the World Economic Forum (since 2006);

- Employment Protection Legislation Index (EPL) developed by the OECD.

Referring to these indicators, it can be summarized that in terms of freedom in the labor market, Poland is classified among the countries with average economic freedom (with a score of 60 points).

The best results are achieved by the United States (in $2014-97.2$ points) and the U.K. (73.1 points). The vast improvement is observed in the Czech Republic (an increase from 57.7 points in 2005 to 84 points in 2014), 
and the reverse trend - in the case of Slovakia (a decrease from 77.1 in 2008 to 53.6 points in 2014).

Figure 3. Index of Economic Freedom in the labor market in Poland and in selected countries of Western Europe and the U.S. in the years 2005-2014

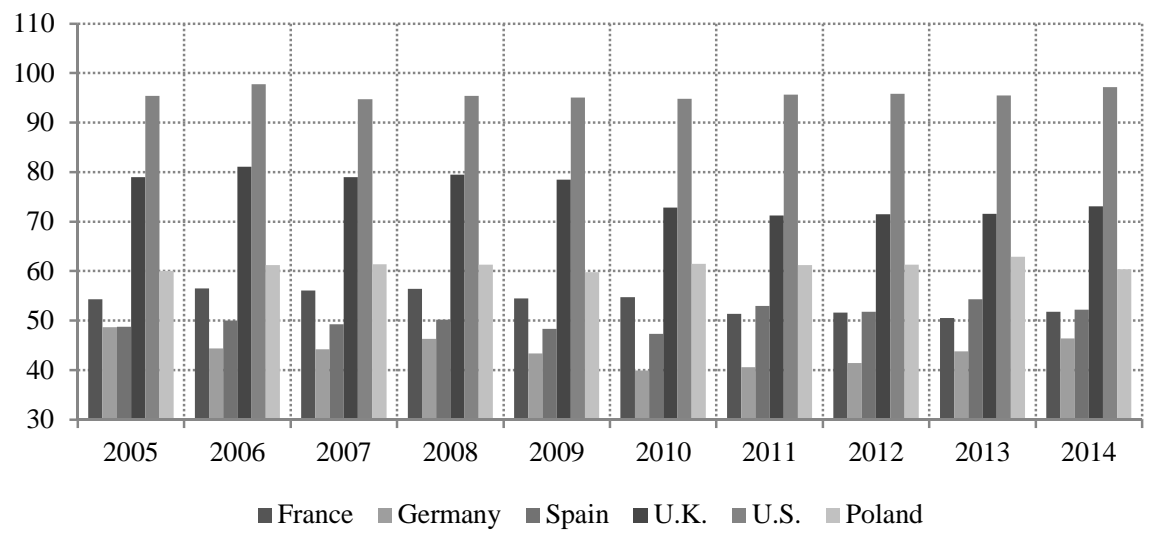

Source: own elaboration based on (Heritage Foundation).

Another institutional indicator is the Index of Labor Market Efficiency, which is a component of Competitiveness Index published by the World Economic Forum. Competitiveness is understood here as "the set of institutions, policies, and factors that determine the level of productivity of a country". The level of productivity, in turn, sets the level of prosperity that can be reached by an economy. The productivity level also determines the rates of return obtained by investments in an economy, which in turn are the fundamental drivers of its growth rates. In other words, a more competitive economy is one that is likely to grow faster over time (The Global Competitiveness Report 2013-2014, p. 4).

In comparison to selected countries of West Europe, Poland obtained results similar to the French market (France with a score of 4.31 in 2013 ranks 71 out of 148 countries, and Poland with a score of 4.20 ranks 80), and far better than Spain (ranks 115 with a score of 3.93). In contrast, in Eastern Europe, the Czech Republic and Slovakia reached a better result in 2008 (4.7), but currently indexes for Poland, Hungary, the Czech Republic and Slovakia remain at a similar level (in 2013, the Slovaks have achieved the result 4.24 and ranks 76, Poles and Czechs -4.20 and rank 80 and 81, and the Hungarians -4.18 and ranks 85 ). 
Figure 4. Labor Market Efficiency Index in Poland and in selected countries of Western Europe and the U.S. in the years 2008-2013

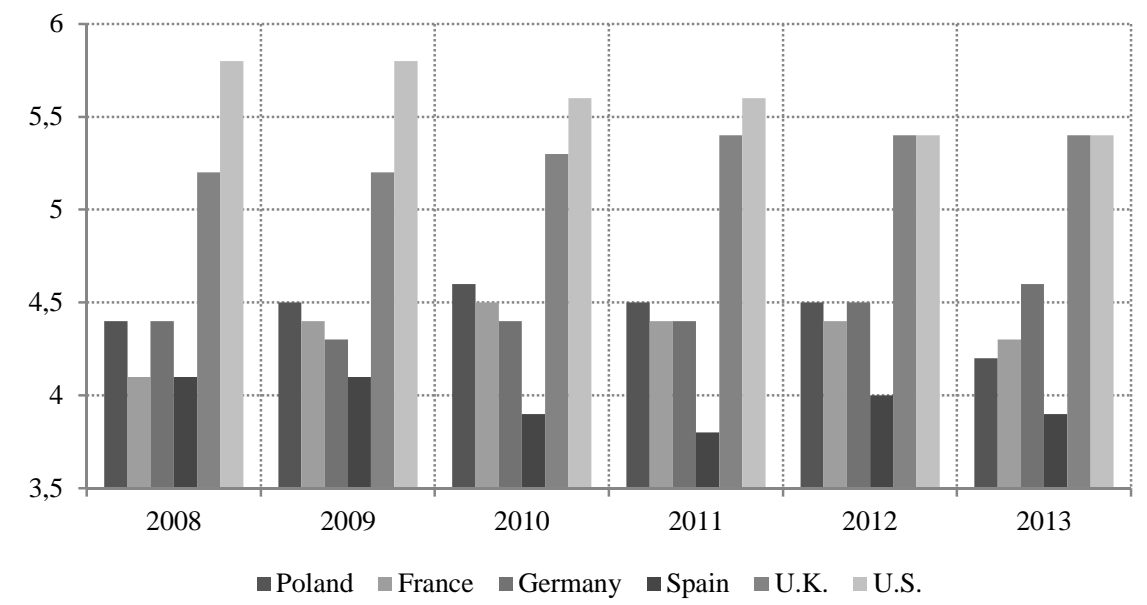

Source: own elaboration based on (The Global Competitiveness Report 2008-2009; 20092010; 2010-2011; 2012-2013; 2013-2014).

To evaluate the flexibility of the labor market, we can refer to employment protection legislation (EPL) index applied by OECD. This indicator measures the procedures and costs involved in dismissing individuals or groups of workers and the procedures involved in employing workers on fixed-term or temporary work agency contracts. EPL index takes value from 0 to 6 (the higher the number, the bigger protection of the labor market) and concerns three areas: individual dismissal of workers with regular contracts, additional costs for collective dismissals and regulation of temporary contracts.

In general, Poland in the years 2000-2013 was characterized by a relatively liberal labor laws in comparison with other transition countries, both in terms of regular contracts, as well for collective dismissals. Meanwhile, in the case of regular contracts we don't observe changes in index of employment protection legislation for Poland (in contrast to the Czech Republic and Slovakia, where the EPL indicators are falling). The exception is the protection of employment for collective dismissals, where the rate fell from 3.38 in 2003 to 2.88 in 2004 . We can therefore conclude that the labor market in Poland has been largely liberalized, but the decline of employment protection mainly reflected in the development of atypical forms of employment. At the turn of the $20^{\text {th }}$ and $21^{\text {st }}$ centuries the workers with temporary contracts constituted 5-6\% of total employment, while at the end of the 
decade, their share exceeded 25\%. As a result, Poland has become the country with the highest ratio of fixed-term workers within the EU. In 2011, the percentage of fixed-term workers in Poland was 26.9, which was almost twice as much as the EU27 average - 14.1 (Bartosik, 2012, p. 35).

Figure 5. Employment Protection Legislation in Poland and in selected countries of Western Europe and the U.S.

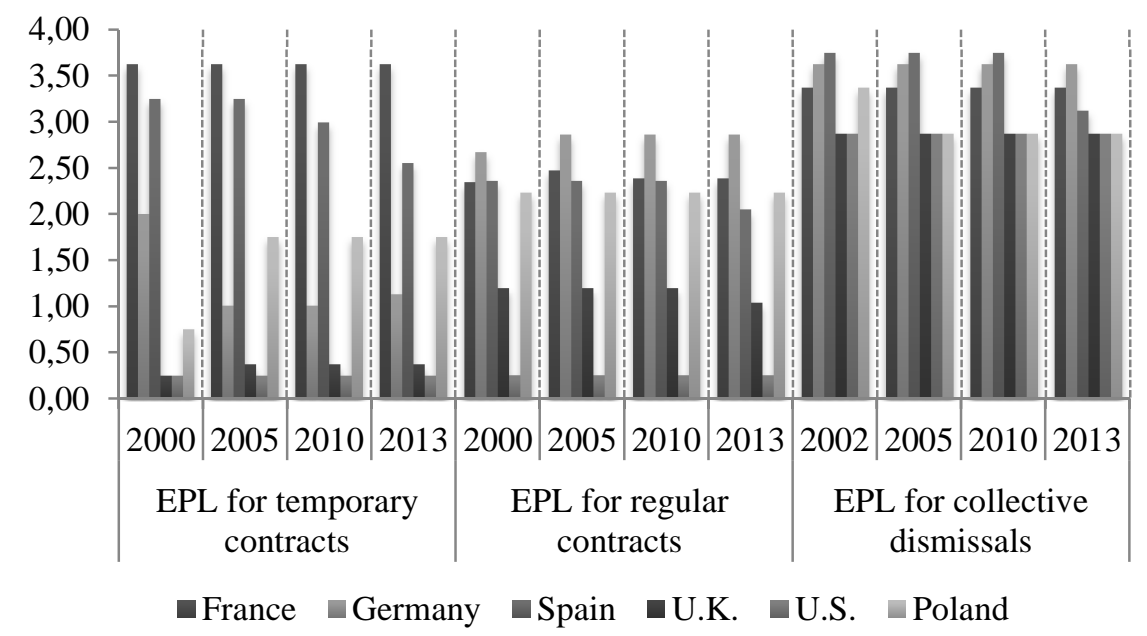

Source: own elaboration based on EPL OECD data (OECD 2014).

Finally to analyze the institutional fundaments of labor market, we should refer also to informal institutions. Without going into details of sociological research, we can quote only the research of Geert Hofstede, Gert Jan Hofstede and Michael Minkov, which shows the type of society and helps to understand the character of the Polish labor market. G.Hofstede analyzed five dimension of culture, which characterize each population (Hofstede, 1991). The first was the distance to authority (distance of employees or citizens from superiors or leaders). In other words, this dimension assesses attitudes toward hierarchy. The second dimension is the level of individualism - whether it is important to achieve the objectives of the individual, or of the whole group. It also draws attention to masculinity or femininity of society. A community, which is more male, clearly defines the social roles of gender and in the case of interests' differences seeks confrontation. In contrast, more feminized society sets the same requirements for both sexes and pays attention to the quality of interpersonal rela- 
tions. In this society the conflicts are solved by negotiation. Societies which are more male are characterized by less professional activity of women. An important dimension is also avoidance of uncertainty - if we accept the changes. Society expecting predictability (avoiding uncertainty) protects itself by creating numerous laws and regulations. Therefore in the case of labor market they will not be willing to deregulation.

Figure 6. Dimensions of national cultures in Poland and in selected countries of Western Europe and the U.S.

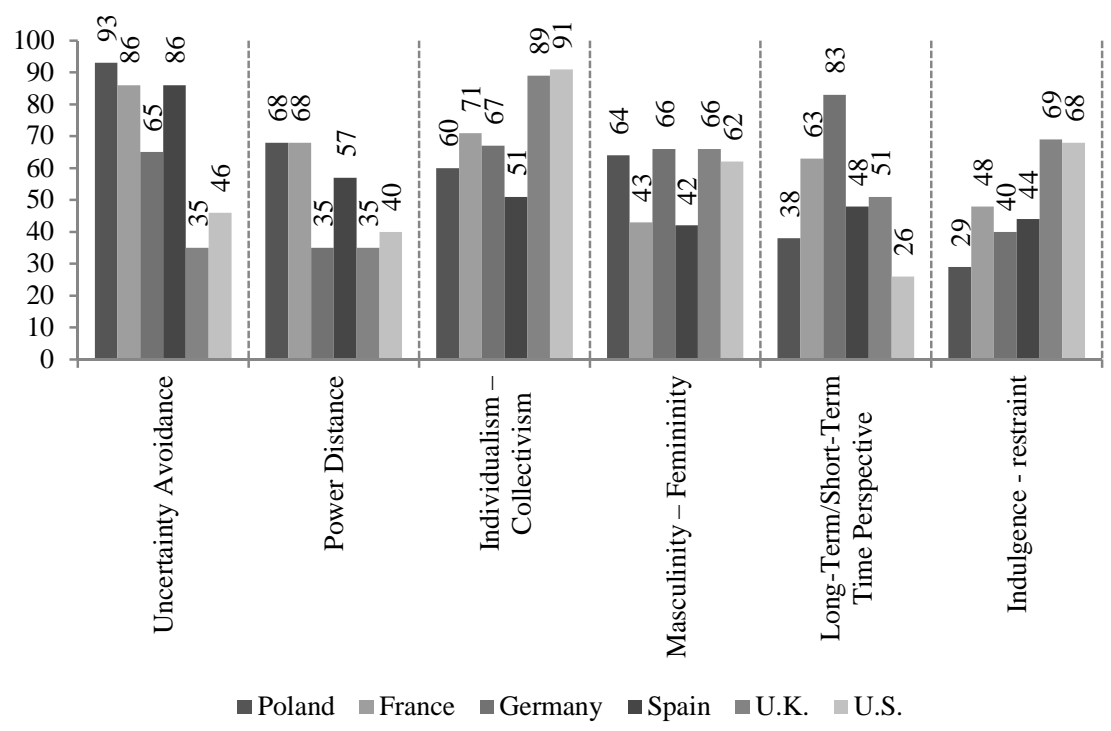

Source: own elaboration based on (Hofstede, et al., 2011, pp. 70-72; 105-106; 150-151; 201$202 ; 260-262 ; 289-291)$.

The research of Hofstedes and Minkov based on European Social Survey and World Values Survey indicates that the Polish society is still male with a medium level of individualism and a large distance to the authorities, pending predictability and avoiding uncertainty, with short-term oriented strategies and rather restrictive (Hofstede, et al., 2011, pp. 70-72; 105-106; 150-151; 201-202; 260-262; 289-291). 


\section{Regional Diversity of Polish Labor Market}

Having presented trends on the Polish Labor Market, I would like to answer the question whether this market is homogeneous. The question is: how do the institutions affect the unemployment and is this impact the same in all regions of Poland?

First, using the index of GDP per capita, which shows indirectly scale of household income and comparing it to the unemployment rate (data for 2011) we can show the placement of the Polish regions in terms of the regional markets development.

Figure 7. GDP per capita and unemployment rate in 2011 by region

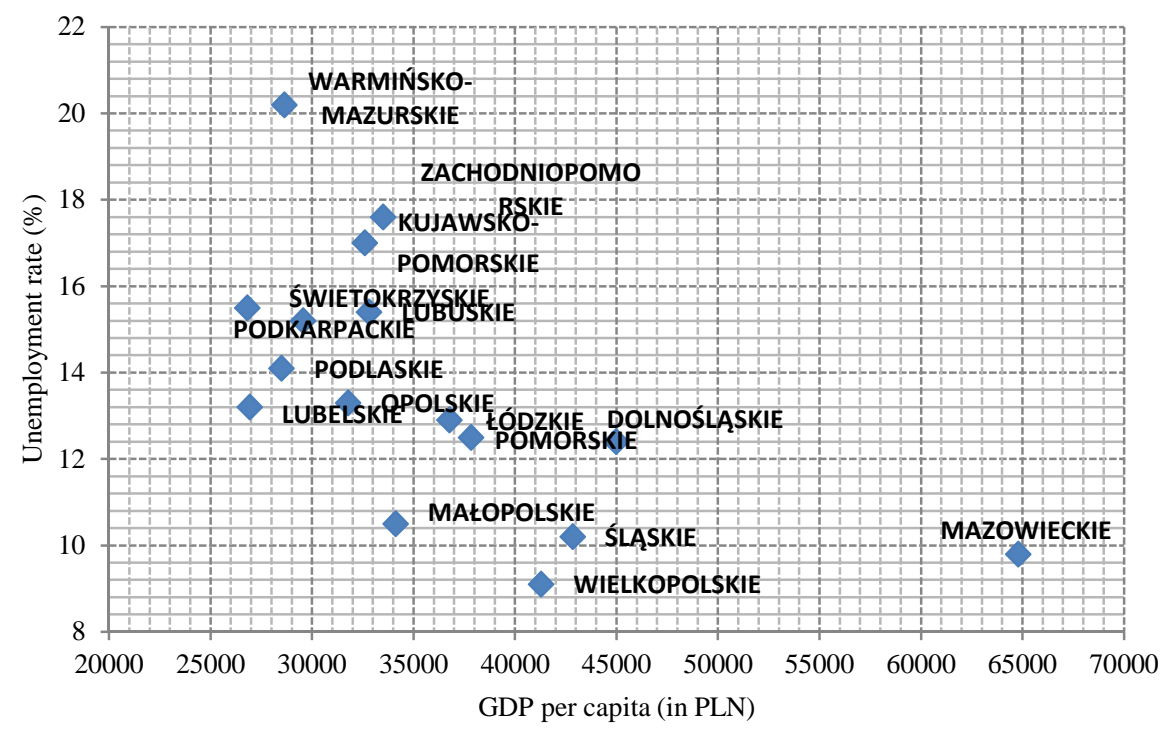

Source: own elaboration based on regional BDL data (GUS 2014).

Figure 7 confirms the existence of the underdeveloped regions, such as Warmia-Mazury, Podkarpackie, Świetokrzyskie and Lubuskie (regions close to the eastern border - the so called Eastern Wall), but also Zachodniopomorskie (region at the western border) and KujawskoPomorskie (central Poland). At the opposite extreme we have Mazowieckie with the capital Warsaw - standing out from the other regions, and further Wielkopolska, Silesia and Malopolska. 
Such important developmental difference between regions in Poland is due to many factors, including long-term underdevelopment and civilization gap, which lead to the threat of permanent marginalization of certain areas. This marginalization is supported by the structural and institutional conditions of local markets.

Figure 8. Activity, employment and unemployment by region in Poland in 2012

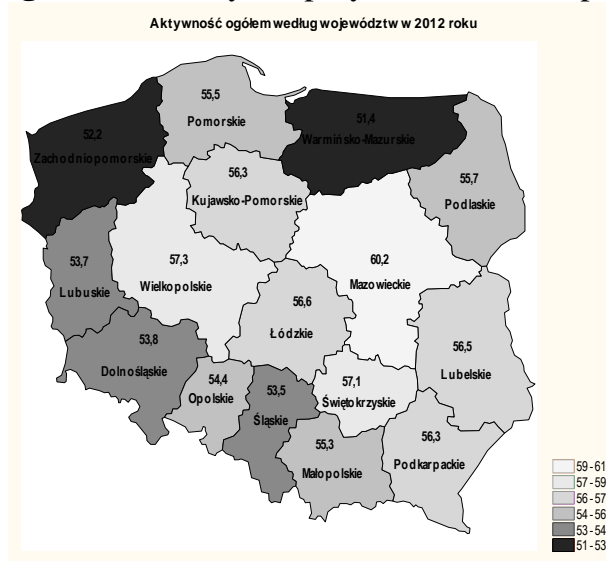

(a) Total activity by region in 2012

Wskaźniki zatrudnienia kobiet według województw w 2012 roku

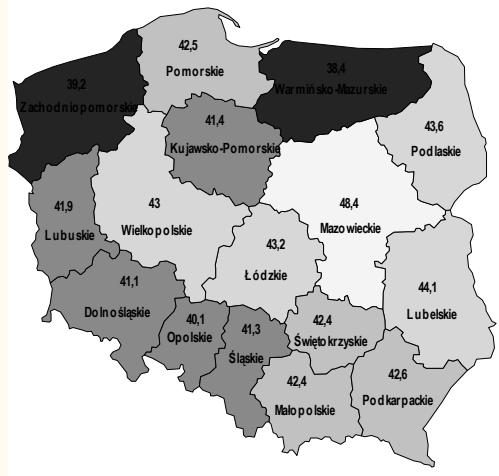

(c) Employment rate for women by region in 2012
Wskaźnikizatrudnienia ogólem wedlug wojewódz tw w 2012 roku

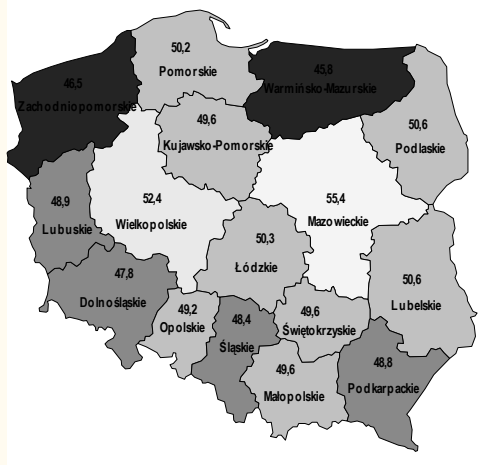

(b) Employment rate by region in 2012

Stopa bezrobocia w Polsce w 2012 roku według województw

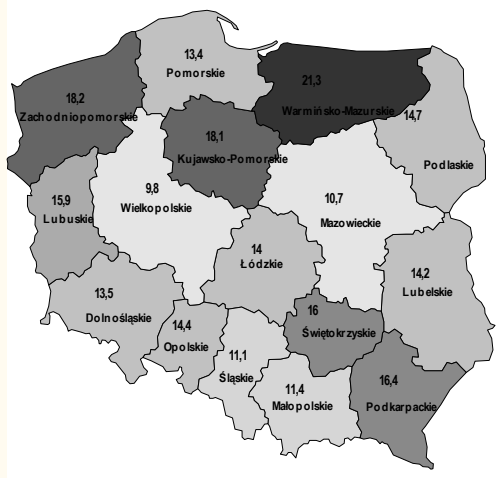

(d) Unemployment rate by region $n$ 2012

Source: own elaboration based on regional data (BDL). 
It should be noted that Poland is still a country with predominantly rural areas (93.1\% of the country). In 2012, those areas had more than 15 million inhabitants (39.3\% of the total population). That causes - contrary to the trends in developed countries - a still high share of employment in agriculture (in 2013 in the Eastern Wall - Lubelskie - 26.5\%, Podlaskie - 24.3\%, Swietokrzyskie $-21.8 \%$, Podkarpackie $-17.9 \%)$. In the eastern regions it is almost twice the national average (13.2\%). Moreover, in Eastern Poland there is a large number of protected areas (almost $40 \%$ of the surface, in the case of Podkarpackie - even more than $60 \%$ of the Małopolska - more than 50\%) (Boni, 2007).

Thus, more than one third of the Polish population permanently living and working in rural areas and the problem for the Eastern Wall is the lack of large cities that constitute the metropolitan facilities for development (especially in Podkarpackie, Swietokrzyskie and Lubelskie).

The scale of structural changes can be seen clearly on the level of regional unemployment. As emphasized at the beginning - at the end of 2013 difference between the lowest (Wielkopolska with 9.6\%) and the highest (Warmia-Mazury with 21.7\%) unemployment rate in the Polish regions was $12.1 \%$. Without the doubt such difference is the result of geographic location, socio-economic development, but also impact of institutions (formal and informal).

\section{Methodology of the Research}

To confirm the significance of institutions' impact, I assumed that the selected quantitative indicators influence the changes in unemployment in regional labor markets. The indicators are the following:

- Average real wage in the corporate sector,

- Gender gap defined as the difference in activity between men and women,

- Kaitz index calculated as the ratio of the minimum wage to the average wage.

I treat wages and Gender gap as manifestations of institutional changes in the labor market.

In my empirical investigations, I use separate panels for regions with good labor market and another for the regions with less developed labor market. The first group consists of Małopolskie, Mazowieckie, Pomorskie, Silesia and Wielkopolskie. The second group consists of KujawskoPomorskie, Podkarpackie, Swietokrzyskie, Warminsko-Mazurskie and 
Zachodniopomorskie. I selected the regions on the basis of unemployment rate in 2012.

In this section I first summarize the statistical properties of the labor market variables. To ensure stationarity, the series is expressed in first differences. This change allows for unifying the observations for the provinces (in contrast to the variables expressed in levels where we observe the trends). I present the descriptive statistics in Table $2 \mathrm{a}$ (in levels) and $2 \mathrm{~b}$ (in first differences).

Observing the descriptive statistics of variables expressed in first differences, the most interesting conclusion concerns the kurtosis, which shows heterogeneity of regional labour markets in Poland. The high kurtosis was observed for Kaitz index (-0.989) in developed regions. Another interesting phenomenon is the differences in kurtosis for unemployment $(-0.287$ for well developed regions and -0.535 for underdeveloped regions) and for gender gap (0.389 and -0.324 respectively). As it is known - kurtosis determines the values distribution and concentration near average. This is particularly important in the case of regional research, because the high kurtosis and leptokurtic distribution show great regional diversity of the studied areas.

Table 2a. Descriptive Statistics of Variables Expressed in levels

\begin{tabular}{|c|c|c|c|c|c|c|c|c|}
\cline { 2 - 9 } \multicolumn{1}{c|}{} & \multicolumn{2}{c|}{ Unemployment } & \multicolumn{2}{c|}{ Real wage } & \multicolumn{2}{c|}{ Gender gap } & \multicolumn{2}{c|}{ Kaitz index } \\
\cline { 2 - 9 } \multicolumn{1}{c|}{} & RD & RLD & RD & RLD & RD & RLD & RD & RLD \\
\hline Mean & 4.167 & 4.449 & 4.833 & 4.814 & 4.835 & 4.710 & 4.535 & 4.658 \\
\hline Median & 4.131 & 4.445 & 4.851 & 4.813 & 4.827 & 4.695 & 4.571 & 4.631 \\
\hline Std. dev. & 0.299 & 0.182 & 0.160 & 0.156 & 0.108 & 0.099 & 0.141 & 0.070 \\
\hline Skewness & 0.240 & -0.302 & -0.091 & -0.010 & 0.056 & 0.503 & -0.704 & 0.266 \\
\hline Kurtosis & -0.616 & -0.153 & -1.457 & -1.506 & -0.280 & -0.148 & -0.073 & -1.564 \\
\hline
\end{tabular}

$\mathrm{RD}$ - regions developed, RLD - regions less developed

Source: own elaboration based on BDL data. 
Table 2b. Descriptive Statistics of Variables Expressed in First Differences

\begin{tabular}{|c|c|c|c|c|c|c|c|c|}
\cline { 2 - 9 } \multicolumn{1}{c|}{} & \multicolumn{2}{c|}{ Unemployment } & \multicolumn{2}{c|}{ Real wage } & \multicolumn{2}{c|}{ Gender gap } & \multicolumn{2}{c|}{ Kaitz index } \\
\cline { 2 - 9 } \multicolumn{1}{c|}{} & RD & RLD & RD & RLD & RD & RLD & RD & RLD \\
\hline Mean & -0.055 & -0.020 & 0.050 & 0.048 & 0.014 & 0.017 & 0.017 & 0.018 \\
\hline Median & -0.079 & -0.011 & 0.051 & 0.049 & 0.014 & 0.007 & 0.002 & 0.004 \\
\hline Std. dev. & 0.184 & 0.128 & 0.020 & 0.020 & 0.072 & 0.077 & 0.044 & 0.041 \\
\hline Skewness & 0.372 & 0.110 & -0.336 & -0.573 & 0.616 & -0.137 & 0.542 & 0.552 \\
\hline Kurtosis & -0.287 & -0.535 & -0.790 & 0.612 & 0.389 & -0.324 & -0.989 & -0.799 \\
\hline
\end{tabular}

$\mathrm{RD}$ - regions developed, RLD - regions less developed

Source: own elaboration based on BDL data.

In order to verify the research hypothesis that the institutions impact the unemployment rate I adopted two studies - Granger causality tests (Granger, 1969, pp. 424-438) and impulse-response analysis. Justifying the choice of this method, I should stress that both tests are well known. Moreover, the feasibility of regional research from the institutional perspective is limited because of data availability. In the case of regional analysis I have to deal with a small number of observations in a large number of regions. Thus, the selection of panel methods. Furthermore, the analysis of the significance of the response function in the impulse-response method can be interpreted in a similar way to Granger causality test.

First, in the analysis of Granger causality tests I used the Sargent procedure (Sargent, 1979, pp. 8-15). In the Sargent procedure, in the first step:

$$
y_{t}=\sum_{i=1}^{k} a_{i} y_{t-i}+\varepsilon_{t} .
$$

In the second run, the regression residuals from (1a) with respect to the variable $\mathrm{x}$ :

$$
\varepsilon_{t}=\sum_{i=1}^{k} \beta_{i} y_{t-i}+\sum_{i=1}^{k} \gamma_{i} x_{t-i}+\eta_{t} .
$$

Tested the hypothesis that the lack of Granger causality from $\mathrm{x}$ to $\mathrm{y}$ is:

$$
H_{0}: \beta_{1}=\beta_{2}=\ldots=\beta_{k}=0 \text {. }
$$

To test the hypothesis (1c) I used likelihood ratio test. 
Then I estimated a VAR model to perform the impulse-response analysis. The general form of the Vector Autoregression Model (VAR) can be written as (Kusideł, 2000, pp. 15-17; Lütkepohl, 2004, p. 88):

$$
y_{t}=A_{1} y_{t-1}+\cdots+A_{p} y_{t-p}+\mu_{t}
$$

Where:

$y_{t}-$ vector containing each of $n$ variables of model: $y_{t}=\left(y_{1 t}, \ldots y_{K t}\right)$

$A_{i}(i=1, \ldots, p)$ - matrices $\mathrm{f}$ parameters of lagged variables of vector $y_{t}$, without zero elements,

$\mu_{t}$ - vectors of stationary random disturbances having an independent Gaussian distribution with zero average and variance $\sum_{\mu}$.

\section{Results of Empirical Investigation}

Table 3 summarizes the Granger causality tests and the signs of the response values.

Table 3. Summary of Granger causality tests and the Impulse-Response Analysis

\begin{tabular}{|c|c|c|c|c|}
\hline \multirow[t]{2}{*}{ Variables } & \multicolumn{2}{|c|}{$\begin{array}{c}\text { Regions with good developed } \\
\text { labor market } \\
\text { (RD) }\end{array}$} & \multicolumn{2}{|c|}{$\begin{array}{c}\text { Regions with less developed } \\
\text { labor market } \\
\text { (RLD) }\end{array}$} \\
\hline & $\begin{array}{c}\text { Granger } \\
\text { causality tests }\end{array}$ & Response & $\begin{array}{c}\text { Granger } \\
\text { causality tests }\end{array}$ & Response \\
\hline $\begin{array}{l}\text { Unemployment } \\
\text { Real wage }\end{array}$ & $\begin{array}{c}\text { Hypothesis } \\
\text { rejected }\end{array}$ & Negative & $\begin{array}{l}\text { Hypothesis non- } \\
\text { rejected }\end{array}$ & Negative \\
\hline $\begin{array}{l}\text { Unemployment } \\
\text { Gender gap }\end{array}$ & $\begin{array}{l}\text { Hypothesis non- } \\
\text { rejected }\end{array}$ & Negative & $\begin{array}{c}\text { Hypothesis } \\
\text { rejected }\end{array}$ & Positive \\
\hline $\begin{array}{l}\text { Unemployment } \\
\text { Kaitz index }\end{array}$ & $\begin{array}{l}\text { Hypothesis non- } \\
\text { rejected }\end{array}$ & Positive & $\begin{array}{l}\text { Hypothesis non- } \\
\text { rejected }\end{array}$ & Positive \\
\hline
\end{tabular}

$\mathrm{RD}$ - regions developed, RLD - regions less developed

Source: own elaboration.

Summing up the results presented in Fig. 9-11, shock in real wages leads to a higher reaction of unemployment in developed regions than in less developed regions, although the results of Granger causality test indicate the significance of real wage for regions with less developed labor markets. On the other hand, the response of unemployment to shock in Gender gap is negative in developed regions and positive - in underdeveloped regions. In turn, the response of unemployment to shock in Kaitz index is positive in all analyzed panels, but the reaction in developed regions 
is two times higher than in less developed areas. Therefore, in all tested panels we observed the positives responses of unemployment to shocks in Kaitz index, but in case of more developed regions Gender gap plays significant role, whereas, in the case of less developed markets, it is real wages.

Figure 9. Impulse Response Analysis Results: Responses of Unemployment to Shocks in Real Wage (RD - regions developed, RLD - regions less developed)

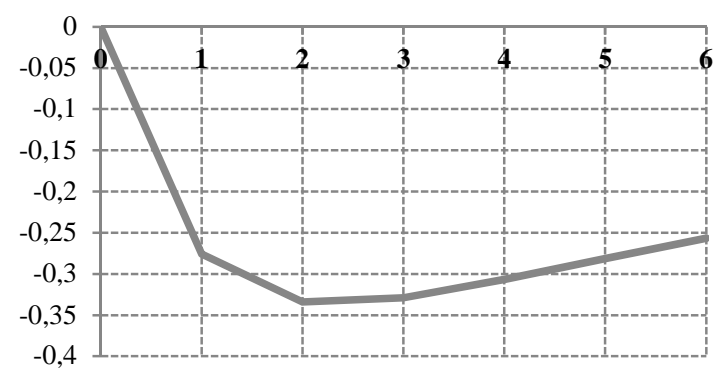

(a) response to shock in real wage, $\mathrm{RD}$

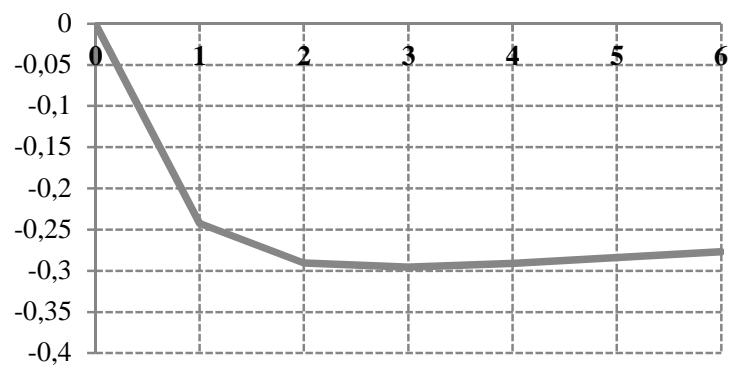

(b) response to shock in real wage, RLD

Source: own elaboration. 
Figure 10. Impulse Response Analysis Results: Responses of Unemployment to Shocks in Gender gap (RD - regions developed, RLD - regions less developed)

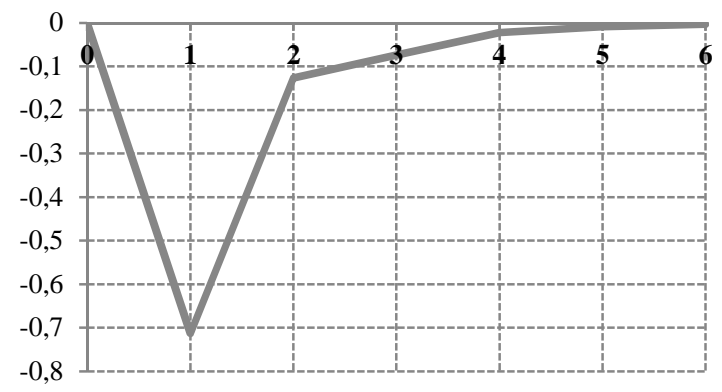

(a) response to shock in Gender gap, $\mathrm{RD}$

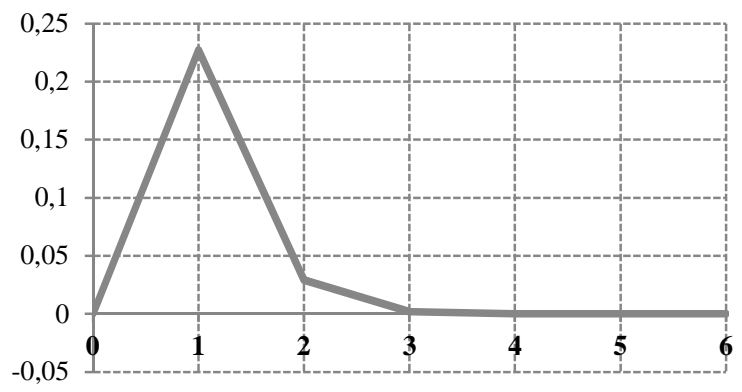

(b) response to shock in Gender gap, RLD

Source: own elaboration.

Figure 11. Impulse Response Analysis Results: Responses of Unemployment to Shocks in Kaitz index (RD - regions developed, RLD - regions less developed)

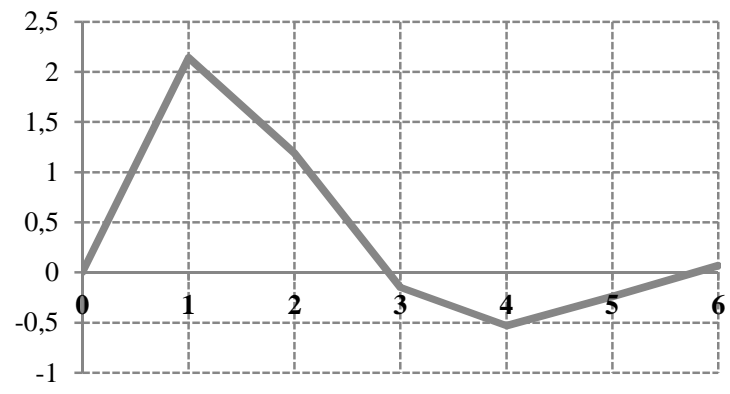

(a) response to shock in Kaitz index, RD 
Figure 11 continued

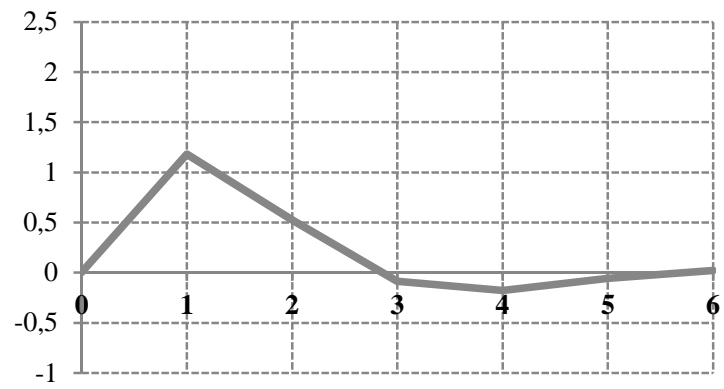

(b) response to shock in Kaitz index, RLD

Source: own elaboration.

Figure 12. Impulse Response Analysis Results: Responses of Real Wage to own Shocks (RD - regions developed, RLD - regions less developed)

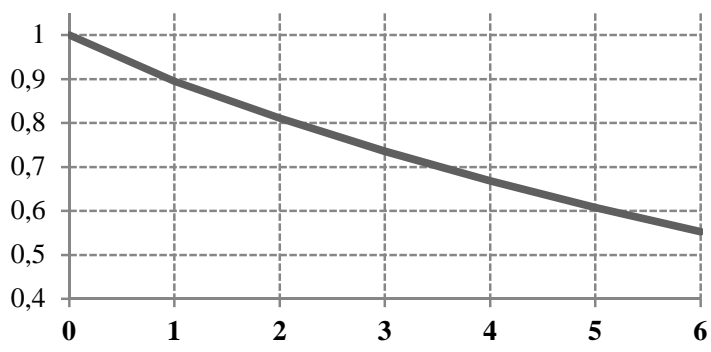

(a) response of Real wage to own shock, RD

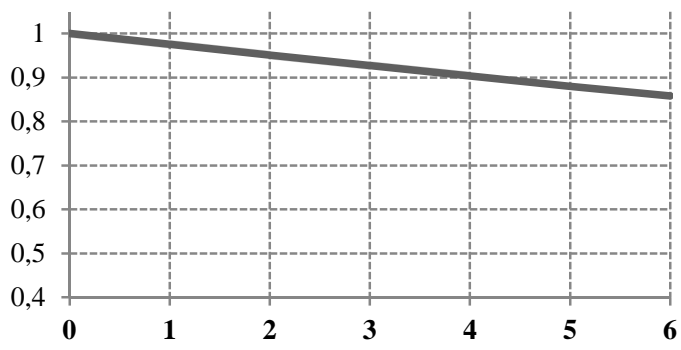

(b) response of Real wage to own shock, RLD

Source: own elaboration. 
Figure 13. Impulse Response Analysis Results: Responses of Gender gap to own Shocks (RD - regions developed, RLD - regions less developed)

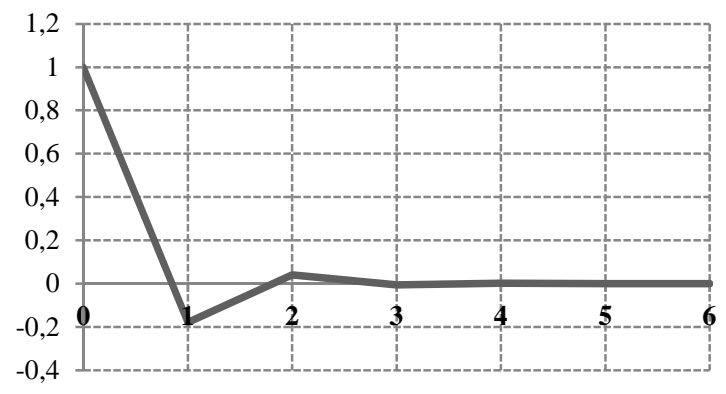

(a) response of Gender gap to own shock, $\mathrm{RD}$

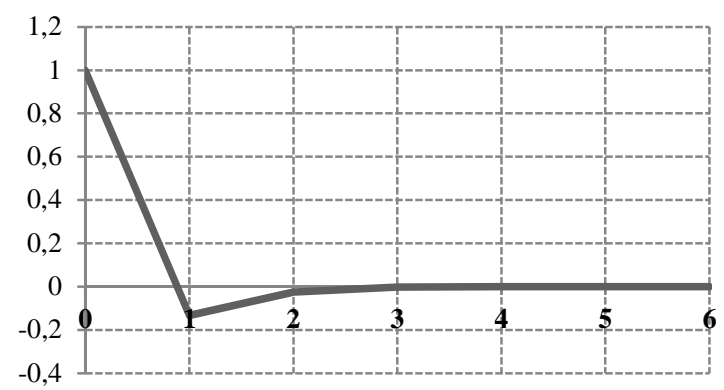

(b) reponse of Gender gap to own shock, RLD

Source: own elaboration.

Figure 14. Impulse Response Analysis Results: Responses of Kaitz index to own Shocks (RD - regions developed, RLD - regions less developed)

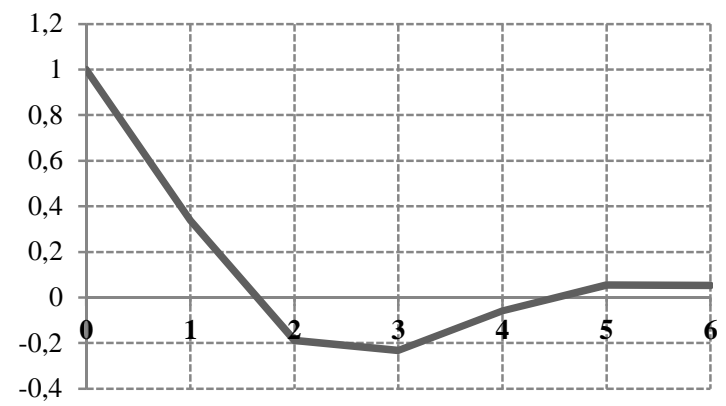

(a) response of Kaitz index to own shock, RD 
Figure 14 continued

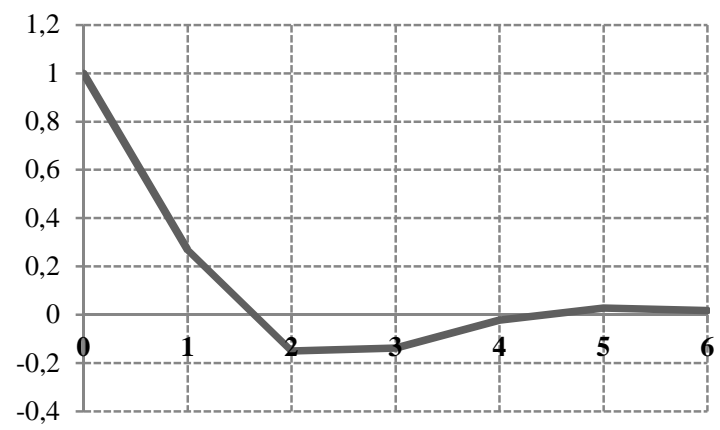

(b) response of Kaitz index to own shock, RLD

Source: own elaboration.

\section{Conclusions}

The efficiency and flexibility of the labor market are critical for ensuring that workers are allocated to their most effective use in the economy and provided with incentives to give their best effort in their jobs. Labor markets must therefore have the flexibility to shift workers from one economic activity to another rapidly and at low cost, and to allow for wage fluctuations without much social disruption. Efficient labor markets must also ensure clear strong incentives for employees and efforts to promote meritocracy at the workplace, and they must provide equity in the business environment between women and men (The Global Competitiveness Report 2013-2014, pp. 6-7).

The main goal of this paper was the description of the Polish Labor Market character and answer to the question if this market is efficient and flexible. For this answer I try to analyze how some institutions as real wage, Kaitz index and Gender gap affect the unemployment and if this impact is the same in all regions of Poland.

My estimations show that both magnitude and the direction of unemployment rate responses differ in developed and less developed regions of Poland. Changes in minimum wages are the most important factor affecting the regional labor market in Poland, but in case of more developed regions Gender gap plays significant role, whereas, in case of less developed markets, it is real wages. These conclusions seem to be particularly important from the perspective of creating recommendations for Polish Labor Market Policy. 


\section{References}

Bartosik, K. (2012). Popytowe i podażowe uwarunkowania polskiego bezrobocia. Gospodarka Narodowa, 11-12.

Boni, M. (2007). Warunki rozwoju Polski Wschodniej w perspektywie 2020. Kapitat ludzki, kapitat społeczny a wyzwania rynku pracy na obszarach Polski Wschodniej. Retrieved from: https://www.mir.gov.pl/rozwoj_regionalny/pozio m_regionalny/strategia_rozwoju_polski_wschodniej_do_2020/dokumenty/Doc uments/c6637615ee384114a83467d692637f9bBoni.pdf (03.09.2014).

Crisis takes its toll: disentangling five years of labor market developments. (2014). In Benchmarking Working Europe 2014, Brussel: ETUI. Retrieved from: www.etui.org/.../file/14+BENCHMARKING+2014+A4+Web+version.pdf (03.09.2014).

OECD. Employment Protection Legislation, Retrieved from: http://150.254.220.12/han/OECDiLibrry/stats.oecd.org/BrandedView.aspx?oec d_bv_id=lfs-data-en\&doi=data-00316-en (03.09.2014).

Granger, C. W. J. (1969). Investigating causal relations by econometric models and cross-spectral methods. Econometrica 37. http://dx.doi.org/10.2307/1912791.

Heritage Foundation, Index of Economic Freedom. Retrieved from: http://www.heritage.org/index/explore?view=by-region-country-year (03.09.2014).

Hofstede, G. (1991). Cultures and Organizations: Software of the Mind. Maidenhead UK: McGraw-Hill.

Hofstede, G. Hofstede G.J. Minkov, M. (2011). Kultury i organizacje. Zaprogramowanie umystu. Warszawa: PWE.

Kusideł, E. (2000). Modele wektorowo-autoregresyjne VAR. Metodologia i zastosowania. In B. Suchecki (Ed.), Dane panelowe i modelowanie wielowymiarowe w modelach ekonomicznych. Łódź: Absolwent. Retrieved from: http://www.kep.uni.lodz.pl/ewakusidel/index/2000_modele_VAR.pdf.

Lütkepohl, H. (2004). Vector Autoregressive and Vector Error Correction Models. In: H. Lütkepohl, M. Krätzig (Ed.), Applied Time Series Econometrics. New York: Cambridge University Press.

North, D.C. (1990). Institutions, Institutional Change and Economic Performance. Cambridge: Cambridge University Press.

Rynek pracy w Polsce w 2013 roku. (2014). Warszawa: Ministerstwo Pracy i Polityki Społecznej, Departament Rynku Pracy. https://psz.praca.gov.pl/documents /10828/153766/Rynek\%20pracy\%20w\%20Polsce\%20w\%202013\%20roku?ver sion $=1.0 \& \mathrm{t}=1403441249157(03.09 .2014)$. 
Sala-i-Martin, X. (2002). 15 Years of New Growth Economics: What Have We Learnt? Discussion Paper Series, \#:0102-47. http://dx.doi.org/10.2139/ ssrn.320765.

Sargent, T. (1979). Estimating vector autoregressions using methods not based on explicit economic theories. Quarterly Review, 3(3).

Schwab, K. (Ed.) (2013). The Global Competitiveness Report 2013-2014. Geneva: World Economic Forum. Retrieved from: http://www.weforum.org/reports/glob al-competitiveness-report-2013-2014 (03.09.2014). 



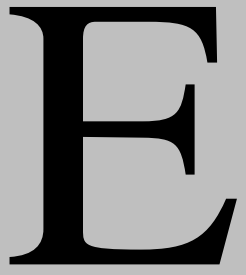

Q U I L I B R I U M

Quarterly Journal of Economics and Economic Policy

\section{Varia}


